\title{
Case of Successful Evolution of Strategy to Create a Sustainable Business Organization: Managerial Implications and Challenges
}

\author{
Gururaj Kulkarni ${ }^{1}$ \\ ${ }^{1}$ Accreditation Board of QCI, Mumbai, India \\ Correspondence: Gururaj Kulkarni, Bldg 3, Flat 402, 4th Floor, Yashodhan Apartments, Four Bungalows, JP \\ Road, Opp. to Kamdhenu Shopping Centre, Andheri-West, Mumbai, India. Tel: \\ 91-976-929-6165/91-222-635-6627. E-mail: gururajk07@gmail.com
}

Received: December 27, 2012

Accepted: January 23, 2013

Online Published: February 20, 2013

doi:10.5539/ijbm.v8n5p96

URL: http://dx.doi.org/10.5539/ijbm.v8n5p96

\begin{abstract}
About couple of decades back, Prince Group was one of the leaders in Plastic Industry. They had occupied No. 2 status in the country. This one particular organization of the Prince Group, was in the business of Manufacturing and Marketing of Injection molded Crates, Blow molded jars, drums, bottles etc. Its main business came from two big multinational organizations who contributed around 75 to $80 \%$ of turnover for the previous 6 to 8 years. However, this demand from these two major customers dropped drastically later. As a result, the turnover of this Organization dropped below by $50 \%$ of earlier level before quietly slipping into loss.

At this juncture, I was invited to join this organization as Strategy Manager. I initiated Strategy Planning process covering both Manufacturing and Marketing functions as a part of recovery process. This case deals with how the strategy was evolved and the Organization implemented the same; hitherto unknown initiatives were taken, what results were achieved both financially and non-financially. Finally, at the end of 3 years this organization bounced back with bang with a decent turnover and profit. In the process, the business had increased by $300 \%$ and increased business level was sustained in spite of exit of two major customer organizations' business.
\end{abstract}

Keywords: strategic planning, deployment, sustained business

\section{Introduction}

This Organization of the Group was launched in 1970s by two young brothers belonging to Gujarati community (who came from Retail Trading background) entered Industry for Manufacture of Injection molded plastic products. The Manufacturing plant was located at Daman, as Govt. of India used to give tax concessions for setting up in Union Territory in those days. For the next 30 years, this organization grew exponentially to become one of the leading Organizations in the country. Its turnover touched a new height of Rs. 95 to 100 Crores (INR 950 to 1000 million) by 2002. With their other brothers also in Plastic Industry and full Group had become No. 2 in India by 1990s.

This organization's main business came from two big Multinationals who contributed to $75 \%$ to $80 \%$ of the turnover in case of Injection molded crates. As the demand shot up around 1997, the Management was quick in setting up an additional Manufacturing facility. So, the Goa Unit was born sometime around 1998. However, by 2003 onwards their demand dipped due to lack of orders from big Multinationals. Its impact on the business of this Organization was quite significant and as a result, its turnover dropped by more than $50 \%$. Besides, it quietly slipped into loss. So, low employee morale prevailed.

It was around this time, through contacts I was invited to join their Organization. I joined in November 2004 as Strategy Manager and my immediate task was very clear; to create a quick recovery.

\section{Planning Phase}

As an Auditor belonging to DNV-who had certified for their ISO 9000 QMS System- I was in-charge of providing all types of audit services to this Organization. Hence, I was having sketchy ideas about the issues faced, more so I was clear that this organization lacked a quality culture.

After becoming familiar with the people of this Organization, I introduced Strategic Planning.

I presented a Roadmap for achieving Business Excellence (Refer Annex 1) in Dec 2004. 
Then, I conducted SWOT (Strengths, Weaknesses, Opportunities and Threats) analysis of the

Organization (Refer Annex 2). Involving the Top and Senior Management personnel, I evolved Mission (dream that the Organization wishes to achieve over few years), Vision (destination to be reached as a first step on that the Organization wishes to reach in next 5 to 8 years) and the Value System to be practiced in the Organization for conducting every business. With this, I made the Team to evolve Long- term and Short-term goals to be achieved by the Organization to achieve the Business Plan of the Organization (Refer Annex 3). After making minor adjustments for the Quality Policy, all the short-term goals were converted into Quality Objectives / Performance goals to be achieved by each and every function in the Organization in the next financial year 2005-2006 (Refer Annex 4).

As a part of Business Strategy, each Regional Sales was advised to achieve the new target which was set at 25\% to $35 \%$ higher than they had achieved in previous year. Manufacturing Units were advised to support the Sale performance target.

I emphasized to the Top Management in each and every supply made to the Customer, the satisfaction must be achieved as it is the only key to succeed in business. It is also the responsibility of the Top Management not only to make people to achieve, but also to improve/enhance this level of satisfaction. I also explained the interpretation of Value System so that the Two Directors mingle this practice into their routine activities too apart advising and applying course corrections. Apart from this, I also made them to understand the Concept of QPC (Quality, Productivity and Cost) Improvement and achieving Quality at Source so that no rework at later stages and thus, becoming a cost effective tool. With this background, I initiated multiple Process / Practice improvements in number of Operational areas at different times. New Processes / Practices were evolved to make the output more effective. They are mentioned in 3.1 to 3.11 steps.

\section{Key Improvement Initiatives}

\subsection{Process Improvement Initiative 1}

With the focus on enhancement of Product Quality, I established systematic method of addressing Customer complaint by evolving Corrective action so that the same or similar complaint does not repeat. To illustrate few chronic issues those were addressed appropriately through use of Ishikawa Diagram (view Page 4 of 10 for a typical diagram) to identify the source of problem. Initiated action to eliminate warpage in Injection Molded Crates which was the biggest headache through evolving a permanent solution; the new process allowed marginally more time for solidifying (which increases cycle time) before taking out from mould and additionally, introduced use of fixture to retain its original shape before it cooled down on the mould.

There used to be another serious complaint of pre-mature breakage of crates whose root cause was identified in Internal Audit. In Raw Material mixing, right proportion was not being practiced; besides, being inconsistent. Very soon this was set right through educating involved people.

Systematic Mould Maintenance programme was established so that consistent quality of Injection Molded crates was achieved. In the whole process, right process got set, right process parameters got established. Thus, the Customer who invariably used to receive warped crate, started receiving warpage defect free one and without pre-mature breakage avoided, he became a satisfied customer.

Right proportion mixing of raw material ensured longer life of the product, thus premature failure in terms of breaking was solved on permanent basis.

There used to be number of complaints of minor avoidable nature. These got eliminated in a new system, DCS. Desptach Clearance System prevented dispatch of wrong cloured, wrong product, in wrong quantity. In addition, bad handling and packing issues were discovered in DCS. With improvement, these issues disappeared once for all. With these actions, all complaints on Product Quality disappeared.

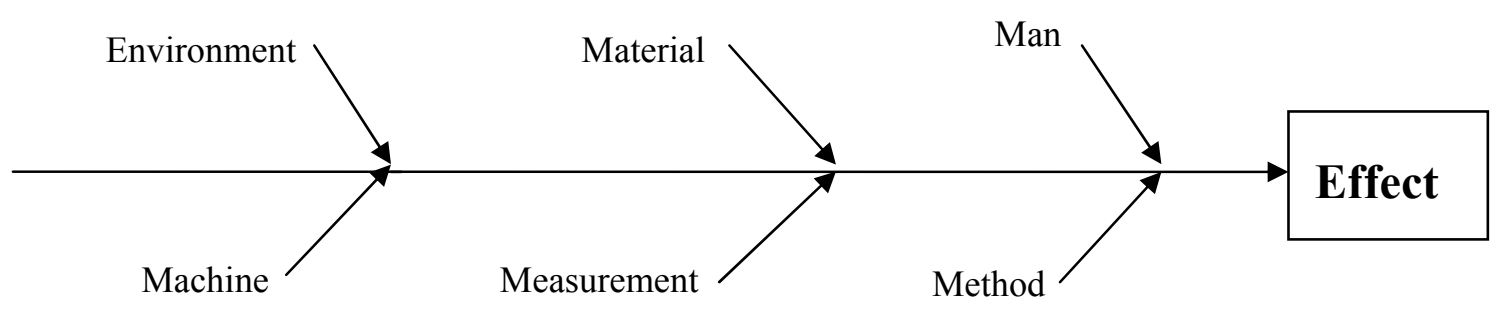

Figure1. Cause-Effect Diagram" or "Fishbone Diagram 
Effect is what you feel at the end of Process; e. g. Warpage.

Process Parameters like; Poor Working of Machine, Error in Measurement of process condition, Incorrect Method of process, Incompetent person working, Incorrect Material composition can contribute to effect like Warping of Injection Moulded Crate.

\subsection{Process Improvement Initiative 2}

Next step was to improve On Time Delivery performance to the customer. After clearing the misconception about difference between Dispatch and Delivery to all involved people in the Organization, few steps were initiated. First of all, transit time from factories (Daman and Goa) to major delivery cities in the country was determined. Based on this all the Transport operating people were taken into confidence and made aware that that our commitment to deliver the product on time and that cannot be fulfilled unless they also adhere to the above determined Transit time. Then each transit time performance was measured and the data of negative variance was shared with Transport operating people. The action set the cycle of evaluation of transit delivery deviations discussed with each transport operator and improvement of their performance commenced. It took some time for real improvements of timely delivery performance by transport operators got shrunk by $20 \%$ and thus, reduced cycle time became routine.

\subsection{Process Improvement Initiative 3}

Next step in this direction was Sales \& Marketing personnel who had complained in the Annual Conference of 2006 that their orders were not getting executed in time and there is a delay usually. Applying Process Approach model, data of time taken for delivering the product from the receipt of Sales order was collected. The analysis of data revealed a fact that Sales \& Marketing were sending Incomplete Data in Orders to HO (in Mumbai) and as a result, the Order could not be executed even if the product is in stock. Analysis showed that nearly $90 \%$ of orders used to be termed as Incomplete; i.e. Non-despatchable. After confirming this trend for 2 to 3 months, a Circular was issued by the Director to all Sales \& Marketing personnel to send only Complete or Despatchable Orders to HO. Within 3 months, the Incomplete Orders level dropped to $10 \%$ from that of $90 \%$. In addition to this, Sales \& Marketing personnel were educated on performing effective Contract Review for each Sales Order. Within 3 months' time, this performance also got enhanced. With this, the On Time Delivery performance improved from $40 \%$ to $70 \%$. The Customers commenced showing some sign of happiness on improved OTD performance.

\subsection{Process Improvement Initiative 4}

As an extension to above, a new system of giving Dispatch Clearance System was introduced at both the factories at Daman and Goa. In this system, an authorised person - who was independent of Production, Despatch was chosen- to administer this function. In this role, he used to verify if the product that is being dispatched is as per Sales Order in terms of Model, Color, Quantity and Quality; in addition, check if the products are packed correctly so that it may not get broken during transit. In case of deviation, he was authorized to stop movement of vehicle till the same was rectified. Initial negative Feedback received from Customer was utilized to sharpen the skill of this authorized person and strengthen the System. When this system got matured in next 3 to 4 month's time, customer complaints on variation of delivered product completely got eliminated. Thus, the new system of Dispatch Clearance System contributed in achieving higher level of Customer Satisfaction.

\subsection{Process Improvement Initiative 5}

There were few complaints on Screen printing that screen printed matter was not visible after putting into use for some time. It was found that correct process was not practiced. Then, the correct screen printing procedure was established in consultation with the manufacturer of screen printing ink. After this, the customers' complaints on this aspect disappeared fully.

\subsection{Process Improvement Initiative 6}

The key Raw material used for all injection moulded material was Polythene granules. Purchase requisitioning was being done in bulk as practiced in olden days. With the change of supply-demand chain or equation in market, this practice was done away. New System of KANBAN (replenish only the consumed quantity) was adopted. This resulted into less stock of costliest raw material in turn less capital employed and need of less storage space in Stores, thus drop in Cost was achieved.

\subsection{Process Improvement Initiative 7}

Quality Assurance Plan which was used to assure quality in product was not effective. Hence, Effective 
Quality Assurance was designed on the basis of scientific sampling plan. As a result, few chronic issues disappeared.

\subsection{Process Improvement Initiative 8}

Concept of DISPATCH PLAN to quote delivery against each Sales Order was established. In this system, tentative Dispatch Plan against each order was sent to each Sales Branch Office was communicated after verifying Stock in FG Store, Tentative Production Plan and with adding transit time of product to the Customer was communicated. Since, this was done for the first time in this Organization, the Customers felt very happy.

\subsection{Process Improvement Initiative 9}

Customer Satisfaction Measurement System was practiced, however, not effective and the emerged data was not utilised. This system was revamped and made it more effective so that it could be used for enhancing Business. Results of the same were shared with the Top Management who was advised to initiate steps for further enhancement through Sales \& Marketing personnel.

\subsection{Process Improvement Initiative 10}

Internal Audit was also being practiced ever since they were certified for ISO 9000 QMS for the previous 8 years. However, found to be not very effective. Additional Training was provided to upgrade the skills of existing Internal Auditors. At the end of each Internal Audit - conducted once in 3 months - the Top Management was apprised of the outcome and this helped in identifying steps of strengthening of practiced system and the same was implemented.

\subsection{Established Process (MIS) to Continue Improvement Initiatives 11}

In order to achieve these improvements, System to Measure Data generated from various processes and identifying Variances was established. This was done once in a quarter. Findings were shared with the Top Management so that course corrections could be evolved and applied.

While establishing the new / improved processes, the operational people were involved fully so as ensure that they own the new processes/ practices. This helped in a big way for sustaining the gain.

The Management was appraised from time to time so that they play their Role of framing Guidelines / Policies and providing resources for implementation.

\section{Few Key Results Achieved}

Table 1. Entire implementation process was over a period of 3 years from 2005 to 2008

\begin{tabular}{|c|c|c|c|c|}
\hline $\begin{array}{l}\text { Sr. } \\
\text { No. }\end{array}$ & Criteria of performance & $\begin{array}{c}\text { Earlier level : } \\
\text { 2004-2005 }\end{array}$ & New Level in 2008 & Remarks \\
\hline 1 & Business Turnover & $\begin{array}{c}\text { Rs. } 40 \text { Crores } \\
\text { (INR } 400 \text { million) }\end{array}$ & $\begin{array}{c}\text { Rs. } 120 \text { Crores } \\
\text { (INR } 1200 \text { million) }\end{array}$ & $300 \%$ rise in 3 years \\
\hline 2 & Profit +/ Loss - & $\begin{array}{l}\text { Rs. - } 10 \text { Cores } \\
\text { (INR } 100 \text { million) }\end{array}$ & $\begin{array}{l}\text { Rs. + } 20 \text { Crores } \\
\text { (INR } 200 \text { million) }\end{array}$ & $\begin{array}{c}\text { Decent Profit earned after } 3 \\
\text { years' period }\end{array}$ \\
\hline 3 & Customer base & $\begin{array}{c}2 \text { Large } \\
\text { Multinationals }+20 \text { to } \\
25 \text { Customers }\end{array}$ & $\begin{array}{l}\text { Additionally, } 75 \text { to } 80 \\
\text { New customers added }\end{array}$ & $\begin{array}{l}\text { Loss of multinationals did } \\
\text { not affect growth of this } \\
\text { Organization }\end{array}$ \\
\hline 4 & $\begin{array}{l}\text { Repeat Order from Small and } \\
\text { Medium sized customer in a } \\
\text { year }\end{array}$ & $\begin{array}{l}\text { Repeat order was a } \\
\text { rare occurrence }\end{array}$ & $\begin{array}{l}\text { It was only repeat } \\
\text { orders from Medium } \\
\text { sized Customers. }\end{array}$ & $\begin{array}{c}\text { Big CHANGE of business } \\
\text { practice for organization }\end{array}$ \\
\hline 5 & $\begin{array}{l}\text { Chronic quality issues from } \\
\text { customers. }\end{array}$ & $\begin{array}{l}\text { Too many customer } \\
\text { complaints on chronic } \\
\text { issues at least } 4 \text { to } 5 \text { a } \\
\text { week. }\end{array}$ & $\begin{array}{l}\text { Customer started } \\
\text { receiving error-free } \\
\text { product. }\end{array}$ & $\begin{array}{l}\text { Customer complaints } \\
\text { dropped by } 75 \% \text { to } 80 \%\end{array}$ \\
\hline 6 & Transit damage & $\begin{array}{l}\text { At least } 2 \text { to } 3 \\
\text { complaints per week }\end{array}$ & $\begin{array}{l}\text { NO/ Zero customer } \\
\text { complaint in } \\
2007-2008\end{array}$ & $\begin{array}{l}\text { Drastic drop of breakage } \\
\text { complaints of crates }\end{array}$ \\
\hline
\end{tabular}




\begin{tabular}{|c|c|c|c|c|}
\hline 7 & $\begin{array}{l}\text { Transit time from factories to } \\
\text { major city in country }\end{array}$ & Base level & $\begin{array}{c}\text { Transit time dropped } \\
\text { by } 20 \% \text { from base } \\
\text { level }\end{array}$ & $\begin{array}{l}\text { Faster delivery to customer } \\
\text { (by } 3 \text { to } 5 \text { days overall) }\end{array}$ \\
\hline 8 & $\begin{array}{c}\text { On Time Delivery (OTD) } \\
\text { performance against agreed in } \\
\text { contract }\end{array}$ & $\begin{array}{l}40 \% \text { orders on time as } \\
\text { per in contract }\end{array}$ & $\begin{array}{c}70 \% \text { orders on time as } \\
\text { per in contract }\end{array}$ & $\begin{array}{l}\text { OTD performance } \\
\text { drastically improved. }\end{array}$ \\
\hline 9 & Customer satisfaction level & $40 \%$ & $75 \%$ & $\begin{array}{c}\text { Customer Satisfaction level } \\
\text { nearly double }\end{array}$ \\
\hline 10 & $\begin{array}{c}\text { Safety - Change over to use of } \\
\text { stainless steel hinges from MS } \\
\text { in Ice Box }\end{array}$ & $\begin{array}{l}\text { MS hinges used to get } \\
\text { rusted inspite of } \\
\text { electroplating (poor } \\
\text { quality plating) }\end{array}$ & No chance of rusting & $\begin{array}{l}\text { Safe usage at enhanced level } \\
\text { to customer }\end{array}$ \\
\hline 11 & $\begin{array}{l}\text { Communication to customer } \\
\text { about tentative date of delivery } \\
\text { at destination }\end{array}$ & $\begin{array}{l}\text { No such system } \\
\text { existed }\end{array}$ & $\begin{array}{l}\text { Now, customer was } \\
\text { informed in advance }\end{array}$ & $\begin{array}{l}\text { Customer welcomed this } \\
\text { change }\end{array}$ \\
\hline 12 & $\begin{array}{l}\text { Effectiveness of Dispatch } \\
\text { Clearance System }\end{array}$ & $\begin{array}{l}\text { No such system } \\
\text { existed }\end{array}$ & $\begin{array}{l}\text { Error free product } \\
\text { received in safe } \\
\text { condition }\end{array}$ & $\begin{array}{c}\text { Customer welcomed this } \\
\text { change }\end{array}$ \\
\hline 13 & Export orders & Nil & $\begin{array}{l}\text { Order from Dubai } \\
\text { received }\end{array}$ & $\begin{array}{l}\text { Export Order received for } \\
\text { the first time. }\end{array}$ \\
\hline 14 & Employee Morale & Low & High & $\begin{array}{l}\text { Enhanced multifold due to } \\
\text { empowering for taking } \\
\text { decisions }\end{array}$ \\
\hline
\end{tabular}

\section{Strategy Evolved and the Result of Implementation}

Thus, different Strategies evolved were:

1) Sales Target to be increased by 30 to $40 \%$ each year so that breakeven point is reached quicker/faster.

2) Improve the Product Quality so that Customer complaints would drop and result in winning the Customer satisfaction.

3) Improve the On Time Delivery (OTD) performance so that the Customer satisfaction enhances.

4) Create sharp drop of waste and process cost in entire system.

5) Develop the Culture of doing the Right the First time through evolving processes that would eliminate generation of product non-conformities in each and every process including all service areas, eliminate rework thus, cutting the Cost.

6) Ensure Management's involvement in all matters that would make above happen on continuous basis. Besides, ensure the Management starts conducting Reviews on regular basis.

7) Develop MIS (Management Information System) that would help to identify areas that would need improvement.

\section{Conclusions}

The above Strategy was implemented for just 3 year period and that too in a Family Managed, tightfisted organization. Against this background, the above mentioned Results are quite significant. The changes I could see were:

- Management started listening to Professional advice,

- Management empowered Professionals to function or take decision without seeking their prior permission,

- Started getting involved in Operations through participating in Review meetings,

- People started taking responsibility for the actions taken by them,

- $\quad$ First time, the whole Organization went into a change gear. 
The above evolved Strategy (fine tuned from time to time) was implemented and it succeeded in turning around this Organization that returned to earning decent profit, besides, achieving 300\% Business growth as seen in above table. With dependence on two major multinationals eliminated, the Customer base got increased. With customer now satisfied with the Product and Service offered, the turnover enhanced that earned profit. Thus, the Business of this Organization became a sustainable.

\section{Few Key Managerial Implications}

- Creation of Turning around a sleeping organization.

- Management's Resistance to change.

- $\quad$ Listening to Professional (unknown to Organization).

- Management empowering Professional to take decision.

- Implementing decisions coming from Professional.

- No habit of being Reviewed and Questioned by Professional.

- No habit of assuming Responsibility when questioned.

\section{Few Key Challenges Faced}

- Changing the mindset of people.

- Changing work culture.

- Convincing the Top Management to change earlier thinking of managing.

- Building quality mind in Top and Senior Management personnel.

- Switching from Factory focused to Customer focus.

- $\quad$ Switching over from taking Correction Action to Corrective Action.

\section{Acknowledgements}

The Author thanks the Top Management, Senior Managerial level personnel and Members of staff at different levels in Head Office, Manufacturing Plants -both Daman and Goa and Regional Sales offices for having extended full support in this journey of transformation.

\section{References}

Galswoth. (1989). "CEDAC" Workshop from Productivity. USA.

Galswoth. (1992). "VCS" Workshop from Productivity. USA.

Gururaj, K. (1991). QPC Improvement (Quality, Productivity and Cost). Addison-Wesley.

Kusaba. (1988). Total Quality Control Concepts. London: MacMillan.

Pralhad, C. K. (1993). Recognized as Management Guru in the World in the field of Strategic Planning.

Robbins, S., \& Judge, T. (2007). Organizational Behaviour (12th ed.). New Jersey: Pearson Education, Inc.

Taichi, O. (1994). JIT System in Toyota Motor Corporation.

Vroom, V. (1964). Work and Motivation. New York: John Willey.

Washio \& Kusaba. (1990). Seminar Policy Deployment and Quality. 


\begin{tabular}{|c|c|c|c|c|}
\hline & Strenthens & Weakeness & Opportunities & Threats \\
\hline $\begin{array}{l}\text { Customer } \\
\text { Related }\end{array}$ & $\begin{array}{l}\text { Strong Brand Image. } \\
\text { Well established relation with } \\
\text { customer. } \\
\text { Very close to few customers: } \\
\text { coke, Pepsi and Amul. } \\
\text { Dominating southern market } \\
\text { share in dairy field. } \\
\text { Good sales network in } \\
\text { southern, western and northern } \\
\text { regions. } \\
\text { Wide and detailed product } \\
\text { range. } \\
\text { No immeditate threat from new } \\
\text { competitor. }\end{array}$ & $\begin{array}{l}\text { Customer focus is weak. } \\
\text { Lack of market research. } \\
\text { Lack of sales promotion } \\
\text { activities. }\end{array}$ & $\begin{array}{l}\text { Growing plastic industry in } \\
\text { country. } \\
\text { Crates and pallets product } \\
\text { have good future. } \\
\text { Good brand image } \\
\text { established. } \\
\text { Resources for developing } \\
\text { new product provided. } \\
\text { Plastic good substitute for } \\
\text { metal(steel: in the wake of } \\
\text { rising prices). } \\
\text { Automobile is growing } \\
\text { sector. } \\
\text { Access to auto sector is } \\
\text { easy. } \\
\text { Economy opening(drop in } \\
\text { import duties) is an } \\
\text { opportunity for price to } \\
\text { expand its business. } \\
\text { Beer industry may use } \\
\text { crates if restrictions are } \\
\text { lifted. } \\
\text { Effect of value added tax } \\
\text { from } 0405 \text {. } \\
\text { Good opportunities for } \\
\text { blow molding product. }\end{array}$ & 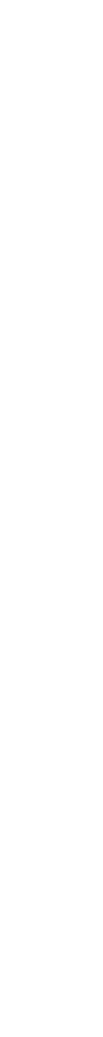 \\
\hline $\begin{array}{l}\text { Management } \\
\text { Related }\end{array}$ & $\begin{array}{l}\text { No compromise on value } \\
\text { principles } \\
\text { Empathetic top management } \\
\text { Manufacturing unit located at } \\
\text { no tax zone }\end{array}$ & $\begin{array}{l}\text { Lack of vision for } \\
\text { conducting business. } \\
\text { Resistance to change at all } \\
\text { levels. } \\
\text { Weak communication at } \\
\text { all levels. } \\
\text { Lack of } \\
\text { empowerment/lack of } \\
\text { delegation at all levels. } \\
\text { Weak measurement, } \\
\text { analysis, review and } \\
\text { improvement system in } \\
\text { organization. } \\
\text { Firefighting system } \\
\text { prevailing at all levels. } \\
\text { Internal audit is not used } \\
\text { as a tool for initiating } \\
\text { improvement actions. } \\
\text { [weak practice of quality } \\
\text { management system } \\
\text { allowed to settle in } \\
\text { organization]. } \\
\text { Follower and not leader in } \\
\text { business. } \\
\text { No killer instinct } \\
\text { approach profitability of } \\
\text { competitor is better than } \\
\text { that of price. } \\
\text { Maximum dependence on } \\
\text { daman. }\end{array}$ & $\begin{array}{l}\text { Contract manufacturing } \\
\text { could be taken up for } \\
\text { similar items(symphony). } \\
\text { Opportunity to convert } \\
\text { prince into learning } \\
\text { organization. }\end{array}$ & \\
\hline
\end{tabular}




\begin{tabular}{|c|c|c|c|c|}
\hline $\begin{array}{l}\text { Resource } \\
\text { Related }\end{array}$ & $\begin{array}{l}\text { Appropriate infrastructure and } \\
\text { other resource provided. } \\
\text { Major supplier-reliance- } \\
\text { practices JIF. }\end{array}$ & $\begin{array}{l}\text { No resource for practicing } \\
\text { structured design and } \\
\text { development approach for } \\
\text { new product development. }\end{array}$ & & $\begin{array}{l}\text { Prevailing unethical } \\
\text { practices by competitor. }\end{array}$ \\
\hline People Related & $\begin{array}{l}\text { Good loyal people in } \\
\text { organization } \\
\text { Willing to learn average age of } \\
\text { employee is around } 35 \text { years. }\end{array}$ & $\begin{array}{l}\text { Lack of clarity on role, } \\
\text { responsibility, authority, } \\
\text { accountability } \\
\text { organization. } \\
\text { Lack of motivation among } \\
\text { employee. } \\
\text { High job security } \\
\text { provided. } \\
\text { Lack of team working. } \\
\text { Retention system is weak. } \\
\text { Close access provided by } \\
\text { top management. }\end{array}$ & $\begin{array}{l}\text { Opportunity for making } \\
\text { personnel more capable } \\
\text { than that of existing. }\end{array}$ & \\
\hline $\begin{array}{l}\text { Knowledge } \\
\text { Related }\end{array}$ & $\begin{array}{l}\text { Capability to handle contract } \\
\text { manufacturing is being } \\
\text { developed. }\end{array}$ & $\begin{array}{l}\text { Low level of knowledge } \\
\text { and skill among all } \\
\text { personnel. } \\
\text { Low level of training } \\
\text { activity. }\end{array}$ & & \\
\hline System Related & & $\begin{array}{l}\text { Logistic system is weak } \\
\text { Lack of effective } \\
\text { utilization of ERP } \\
\text { Real system corrections } \\
\text { are not evident. } \\
\text { Not flexible in changing } \\
\text { product mix. } \\
\text { Person dependent and not } \\
\text { system dependent. }\end{array}$ & & \\
\hline Constraints & & $\begin{array}{l}\text { Customer demands } \\
\text { product at lower price. } \\
\text { No control over price of } \\
\text { raw material. } \\
\text { High capital intensive } \\
\text { industry. } \\
\text { Low value added business } \\
\text { chosen (RM70\% of } \\
\text { value). }\end{array}$ & 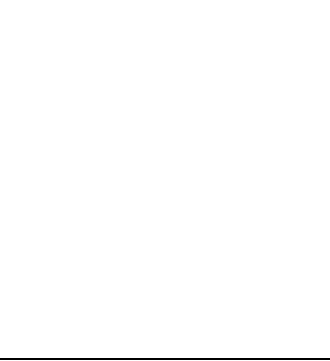 & $\begin{array}{l}\text { Weather dependent } \\
\text { product dependent on } \\
\text { crude oil whose price in } \\
\text { international market is } \\
\text { varying. } \\
\text { Tax holiday may end } \\
\text { soon. }\end{array}$ \\
\hline
\end{tabular}

